\title{
Antioxidative ability of ethanol extract from the leaves of Leucaena leucocephala (Lam.) de Wit
}

\author{
Dong Chung Kim ${ }^{1} \cdot$ Man-Jin In $^{2}$ \\ 백연수(Leucaena leucocephala (Lam.) de Wit) 잎 에탄올 추출물의 \\ 항산화능
}

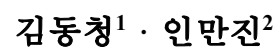

Received: 25 May 2017 / Accepted: 20 June 2017 / Published Online: 30 June 2017

(C) The Korean Society for Applied Biological Chemistry 2017

\begin{abstract}
Antioxidative ability of 50\% ethanol extract from leaves of Leucaena leucocephala (Lam.) de Wit was investigated. The extraction yield, total polyphenols and total flavonoids of the ethanol extract were $18.3 \pm 0.40 \%, 121.3 \pm 11.04 \mu \mathrm{g}$ gallic acid equivalents/mg and $105.2 \pm 2.77 \mu \mathrm{g}$ quercetin equivalents $/ \mathrm{mg}$, respectively. The ethanol extract possessed the antioxidative activities such as free radical, cation radical, and nitrite scavenging activities as well as reducing power and lipid peroxidation inhibitory activity. These antioxidative activities of the ethanol extract increased in proportion to the extract concentration. $\mathrm{EC}_{50}$ values for free radical scavenging, cation radical scavenging nitrite scavenging, and reducing power were $133.51 \mu \mathrm{g} / \mathrm{mL}$, $667.22 \mu \mathrm{g} / \mathrm{mL}, \quad 2.58 \mathrm{mg} / \mathrm{mL}$, and $250.00 \mu \mathrm{g} / \mathrm{mL}$, respectively. Polyphenols and flavonoids are suggested to be the key contributors for the antioxidative ability of the ethanol extract from Leucaena leucocephala leaves.
\end{abstract}

Man-Jin In $(\bowtie)$

E-mail: manjin@chungwoon.ac.kr

${ }^{1}$ Department of Integrated Materials Engineering, Chungwoon University, Incheon 22100, Republic of Korea

${ }^{2}$ Department of Human Nutrition and Food Science, Chungwoon University, Hongseong 32244, Republic of Korea

This is an Open Access article distributed under the terms of the Creative Commons Attribution Non-Commercial License (http://creativecommons. org/licenses/by-nc/3.0/) which permits unrestricted non-commercial use, distribution, and reproduction in any medium, provided the original work is properly cited.
Keywords Antioxidative ability · Ethanol extract · Flavonoid · Leucaena leucocephala $\cdot$ Polyphenol

\section{서 론}

Leucaena leucocephala (Lam.) de Wit는 멕시코 기원의 열대 콩과(Fabaceae) 식물로 현재는 중부 아메리카, 아프리카, 아시 아, 호주 북부 등 강수량이 풍부한 열대와 아열대지역에 널리 분포되어 있는 나무이다. 이 나무는 가시가 없는 상록수로 10$20 \mathrm{~m}$ 높이까지 자라며 $12-14 \mathrm{~cm}$ 꼬투리에 15-30개의 종자를 함 유한 열매를 맺는다(Pandey와 Kumar 2013). 일반적으로 jumbay 혹은 white lead tree로 불리며 우리나라에서는 생육이 곤란하여 잘 알려지지 않은 식물이나 일반명인 white lead tree 를 직역하여 백연수(白鉛樹)로 불리기도 한다. 백연수가 널리 분 포하는 인도와 동남아시아에서 이 나무는 사료, 목재, 유기비료 로 많이 사용되며, 펄프와 종이뿐만 아니라 식품과 의약품의 원 료로도 이용되고 있다(López 등, 2008). 특히 잎은 단백질 함량 이 우수하여 가축의 단백질 공급원으로 매우 효과적이며 (Echeverría 등, 2002), 어린 잎, 종자, 꽃 봉오리, 미숙 꼬투리 와 줄기 등은 샐러드나 음식의 원료로 소비되고 있다(Nehdi 등, 2014). 백연수 종자에는 아이스크림, 화장품, 의약품 원료로 사 용되는 아라비아 검(gum Arabic)과 유사한 galactomannan gum 과 불포화 지방산인 올레산과 리놀레산의 함량이 높은 지방이 6-8\% 함유되어 있으며(Nehdi 등, 2014; Mittal 등, 2016), 예로 부터 멕시코와 중미 원주민은 종자를 식용으로 섭취하였으며 커 피의 대체품으로도 이용하였다. 또한 대체의학 분야에서 당뇨병 환자에게 처방되는 백연수 종자는 혈당 상승을 저해하며 랑게 
르한스섬 수를 증가시키는 항당뇨 활성을 갖는 것으로 보고되 어 있다(Syamsudin 등, 2010; Chowtivannakul 등, 2016). 백연 수 종자 이외에 잎은 사료로 나무와 줄기는 종이와 펄프제조 등에 사용되고 있으며, 어린 잎의 일부가 식용으로 이용됨에도 불구하고 백연수의 생리적인 기능성에 대한 연구는 매우 미흡 한 실정이다.

따라서 본 연구에서는 백연수 잎의 에탄올 추출물을 시료로 하여 폴리페놀과 플라보노이드 성분의 함량을 확인하고, 유리라 디칼 소거활성, 양이온라디칼 소거활성, $\mathrm{Fe}^{3+}$ 이온 환원력, 아질 산염 소거활성 및 지질과산화 억제활성을 측정하여 항산화 활 성을 확인함으로써 백연수 잎의 용도 확대에 기여하고자 한다.

\section{재료 및 방법}

\section{재료 및 에탄올 추출물 제조}

건조된 백연수 잎은 태국산(Yoarreum Yoahaeng Trading Co., Bangkok, Thailand)으로 $60{ }^{\circ} \mathrm{C}$ 에서 한번 더 열풍건조하여 분쇄 한 후 $100-300 \mu \mathrm{m}$ 크기의 분말만을 사용하였다. 백연수 잎 분 말에 10 배 $(\mathrm{w} / \mathrm{w})$ 의 $50 \%$ 에탄올을 넣고 항온 진탕조에서 1 시간 동안 진탕시켜 추출하고 여과지(Whatman filter No. 2)로 거른 후 감압 농축하여 백연수 잎 추출물을 제조하였다.

\section{총 폴리페놀 함량}

백연수 잎 추출물에 함유된 총 폴리페놀 함량은 Folin-Ciocalteu 시약을 이용한 발색 방법(Folin과 Denis 1912)으로 측정하였다. 백연수 잎 추출물 $1 \mathrm{~mL}$ 와 Folin-Ciocalteu 시약 $2 \mathrm{~mL}$ 를 혼합하 여 상온에서 3 분간 반응시킨 후, $10 \% \mathrm{Na}_{2} \mathrm{CO}_{3}$ 용액을 $2 \mathrm{~mL}$ 첨가하여 상온에서 1시간 정치시킨 다음 $760 \mathrm{~nm}$ 에서 흡광도를 측정하였다. 표준물질로 gallic acid를 사용하여 추출물 $\mathrm{mg}$ 당 $\mu \mathrm{g}$ gallic acid equivalent (GAE)로 나타내었다.

\section{총 플라보노이드 함량}

백연수 잎 추출물에 함유된 총 플라보노이드 함량은 백연수 잎 추출물 $1 \mathrm{~mL}$ 에 diethyleneglycol $2 \mathrm{~mL}$ 와 $1 \mathrm{~N} \mathrm{NaOH} 0.02 \mathrm{~mL}$ 를 혼합하여 $37^{\circ} \mathrm{C}$ 에서 1시간 방치한 후 $420 \mathrm{~nm}$ 에서 흡광도를 측정하였다(Boo 등, 2009). 표준물질로 quercetin을 사용하여 추 출물 $\mathrm{mg}$ 당 $\mu \mathrm{g}$ quercetin equivalent $(\mathrm{QE})$ 로 나타내었다.

\section{DPPH 유리라디칼 소거활성}

유리라디칼 소거활성은 Blois의 방법을 이용하여 2,2-diphenyl1-picryl-hydrazyl (DPPH) 유리라디칼에 대한 환원력을 측정하 였다(Blois 1958). 백연수 잎 추출물 $1 \mathrm{~mL}$ 와 $0.15 \mathrm{mM} \mathrm{DPPH}$ 용액 $3 \mathrm{~mL}$ 를 혼합하여 상온에서 30 분 동안 정치시킨 후 525 $\mathrm{nm}$ 에서 흡광도를 측정하였다. 백연수 잎 추출물의 유리라디칼 소거활성은 (1-추출물 첨가군의 흡광도/무첨가군의 흡광도) $\times 100$ 에 따라 계산하였고, 대조군으로 vitamin $\mathrm{C}$ 를 사용하였다.

\section{ABTS 양이온라디칼 소거활성}

양이온라디칼 소거활성은 $\operatorname{Re}$ 등의 방법에 따라 2,2'-azinbis-(3ethyl-benzothiazoline)-sulfonic acid (ABTS) 양이온라디칼에 대 한 환원력을 측정하였다( $\operatorname{Re}$ 등, 1999). 최종 농도로 $7.4 \mathrm{mM}$
$\mathrm{ABTS}$ 와 $2.6 \mathrm{mM}$ potassium persulfate가 혼합된 용액을 만들어 암소에서 15 시간 정치함으로써 $\mathrm{ABTS}$ 양이온라디칼 $\left(\mathrm{ABTS}^{+}\right)$을 형성시킨 후 $414 \mathrm{~nm}$ 에서의 흡광도가 $1.5 \pm 0.02$ 가 되도록 희석하 여 ABTS 라디칼 용액을 만들었다. 백연수 잎 추출물 $0.15 \mathrm{~mL}$ 와 $\mathrm{ABTS}$ 라디칼 용액 $3 \mathrm{~mL}$ 를 혼합하여 상온에서 90 분간 반 응시킨 후 $414 \mathrm{~nm}$ 에서 흡광도를 측정하였다. 백연수 잎 추출물 의 양이온라디칼 소거활성은 유리라디칼 소거활성과 동일한 수 식으로 계산하였고, 대조군으로 vitamin $\mathrm{C}$ 를 사용하였다.

\section{아질산염 소거활성}

백연수 잎 추출물 $1 \mathrm{~mL}$ 를 $1 \mathrm{mM} \mathrm{NaNO}$ 용액 $1 \mathrm{~mL}$ 와 혼합한 후 $0.2 \mathrm{M}$ 구연산 완충액 $(\mathrm{pH} \quad 1.2) 8 \mathrm{~mL}$ 를 가하여 $37^{\circ} \mathrm{C}$ 에서 1 시간 반응시켰다. 반응액 $1 \mathrm{~mL}$ 를 취하여 $2 \%$ 초산 용액 $3 \mathrm{~mL}$ 와 Griess 시약 $0.4 \mathrm{~mL}$ 를 혼합하고 실온에서 15 분 동안 정치시 킨 후 $520 \mathrm{~nm}$ 에서 흡광도를 측정하였다(Gray와 Dugan 1975). 백연수 잎 추출물의 아질산염 소거활성은 추출물 무첨가군에 대 한 첨가군의 흡광도비 $(\%)$ 로 계산하였고, 대조군으로 vitamin $\mathrm{C}$ 를 사용하였다.

\section{환원력}

$0.2 \mathrm{M}$ 인산 완충액(pH 6.6) $2.5 \mathrm{~mL}$ 에 백연수 잎 추출물 $1 \mathrm{~mL}$ 와 $1 \% \mathrm{~K}_{3} \mathrm{Fe}(\mathrm{CN})_{6}$ 용액 $2.5 \mathrm{~mL}$ 를 혼합하여 $50{ }^{\circ} \mathrm{C}$ 에서 20 분 간 반응시키고 $10 \%$ trichloroacetic acid 용액 $2.5 \mathrm{~mL}$ 를 가한 후 원심분리 $(1,000 \times \mathrm{g}, 5 \mathrm{~min})$ 하였다. 상등액 $2.5 \mathrm{~mL}$ 와 증류수 $2.5 \mathrm{~mL}$ 를 섞은 후 $0.1 \% \mathrm{FeCl}_{3}$ 용액 $0.5 \mathrm{~mL}$ 를 가하고 $700 \mathrm{~nm}$ 에서 흡광도를 측정하였다(Oyaizu 1985). 백연수 잎 추출물의 환원력은 흡광도 값으로 나타내었고, 대조군으로 vitamin $\mathrm{C}$ 를 사용하였다.

\section{지질과산화 억제활성}

Linoleic acid를 $2.52 \mathrm{mg} / \mathrm{mL}$ 의 농도로 $99.5 \%$ ethanol에 녹여 불포화지방산 용액을 제조하였다. $50 \mathrm{mM}$ 인산 완충액 $(\mathrm{pH} 7.0)$ $4.0 \mathrm{~mL}$ 에 백연수 잎 추출물 $2 \mathrm{~mL}$, 불포화지방산 용액 $2.05 \mathrm{~mL}$ 와 증류수 $1.95 \mathrm{~mL}$ 를 혼합하여 $45^{\circ} \mathrm{C}$ 에서 48 시간 동안 incubation 하였고, 시간별로 지질과산화 시료를 채취하였다. 백연수 잎 추 출물의 지질과산화 억제활성은 ferric thiocyanate법을 이용한 과 산화물 측정법으로 확인하였다(Nakatani와 Kikuzaki 1987). 지 질과산화 시료 $0.1 \mathrm{~mL}$ 과 $30 \%$ ammonium thiocyanate $0.1 \mathrm{~mL}$ 를 순차적으로 $75 \%$ ethanol $4.7 \mathrm{~mL}$ 에 넣고 실온에서 5 분간 정 치한 후 $20 \mathrm{mM}$ ferrous chloride $0.1 \mathrm{~mL}$ 을 혼합하고 $500 \mathrm{~nm}$ 에서 흡광도를 측정하였다. 백연수 잎 추출물의 지질과산화 억 제활성은 (1-추출물 첨가군의 흡광도/무첨가군의 흡광도) $\times 100$ 에 따라 계산하였고, 대조군으로 vitamin $\mathrm{E}$ 를 사용하였다.

\section{결과 및 고찰}

백연수 잎을 다양한 농도의 에탄올 용액으로 추출하여 총 폴리 페놀 함량과 유리라디칼 소거활성을 비교하였고, 폴리페놀 성분 이 가장 많이 얻어진 $50 \%$ 에탄올 용액을 백연수 잎의 추출용 매로 결정하였다. 백연수 잎을 $50 \%$ 에탄올로 추출하였을 때, 추출 수율은 $18.3 \pm 0.40 \%$ 이었다(Table 1). 백연수 잎의 $50 \%$ 에 
Table 1 Yield, total polyphenol and total flavonoid content of $50 \%$ ethanol extract from Leucaena leucocephala leaves

\begin{tabular}{|c|c|c|}
\hline Yield (\%) & $\begin{array}{c}\text { Total polyphenols }{ }^{1)} \\
\text { ( } \mu \text { g GAE/mg solid extract) }\end{array}$ & $\begin{array}{c}\text { Total flavonoids }{ }^{2)} \\
\text { ( } \mu \mathrm{g} \mathrm{QE} / \mathrm{mg} \text { solid extract) }\end{array}$ \\
\hline $18.3 \pm 0.40$ & $121.3 \pm 11.04$ & $105.2 \pm 2.77$ \\
\hline
\end{tabular}

탄올 추출물의 총 폴리페놀 함량은 $121.3 \pm 11.04 \mu \mathrm{g} \mathrm{GAE} / \mathrm{mg}$ 로 매우 높게 나타났다(Table 1). 이는 $70 \%$ 아세톤으로 제조한 백 연수 잎 추출물의 총 폴리페놀 함량인 $3.21 \mu \mathrm{g} \mathrm{GAE} / \mathrm{mg}$ (Zarin 등, 2016)과 백연수 종자 $80 \%$ 에탄올 추출물의 총 폴리페놀 함 량인 $37.38 \mu \mathrm{g} \mathrm{GAE} / \mathrm{mg}$ (Chowtivannakul 등, 2016)보다 월등 하게 높은 것이며, 이러한 차이는 추출 용매의 상이함에 기인 하는 것으로 판단된다. 또한 백연수 잎의 $50 \%$ 에탄올 추출물 의 총 플라보노이드 함량도 $105.2 \pm 2.77 \mu \mathrm{g} \mathrm{QE} / \mathrm{mg}$ 로 매우 높게 나타났다(Table 1). 식물에 널리 존재하는 페놀성 화합물은 phenol류, phenolic acid류, flavonoid류 및 phenylpropanoid류 등을 포함하며 그 구조의 phenolic hydroxyl기 때문에 항산화 능력을 갖는 것으로 알려져 있다(Amin과 Yazdnparast 2007). 약용식물 10 종(황금, 오가피, 갈근, 쇠비름, 산사, 참빗살나무, 헛 개나무, 화피, 합환피, 감국)의 $70 \%$ 에탄올 추출물의 총 폴리페 놀 및 플라보노이드 함량을 측정한 보고에 따르면, 총 폴리페 놀 함량은 tannic acid를 기준 물질로 하여 $21.67-320.10 \mu \mathrm{g} / \mathrm{mg}$ 이었고, 총 플라보노이드 함량은 rutin을 기준 물질로 하여 3.90$226.25 \mu \mathrm{g} / \mathrm{mg}$ 으로 분포가 다양하였다(Joo 2013). 화피의 $70 \%$ 에탄올 추출물의 경우, 총 폴리페놀과 플라보노이드 함량이 각 각 $320.10 \mu \mathrm{g} / \mathrm{mg}$ 과 $226.25 \mu \mathrm{g} / \mathrm{mg}$ 으로 가장 높았다(Joo 2013). 물엉겅퀴 잎과 섬고사리 잎의 총 폴리페놀 함량은 각각 130.22 와 $120.69 \mu \mathrm{g} / \mathrm{mg}$ (Lee 등, 2005)으로 보고되어 백연수 잎 에탄 올 추출물의 폴리페놀 함량과 비슷한 수준이었다. 물엉겅퀴 잎 과 섬고사리 잎의 총 플라보노이드 함량은 각각 16.75 와 13.30 $\mu \mathrm{g} / \mathrm{mg}$ (Lee 등, 2005)으로 나타나 백연수 잎 에탄올 추출물의 플라보이드 함량이 월등히 높았다. 플라보노이드는 페놀성 화합 물의 범주에 속하는 물질로 대부분의 연구(Lee 등, 2005; Ju 등,
Table 2 Comparison of antioxidative activities of $50 \%$ ethanol extract of the leaves of Leucaena leucocephala and vitamin C

\begin{tabular}{|c|c|c|}
\hline \multirow[b]{2}{*}{ Antioxidative activities } & \multicolumn{2}{|c|}{$\mathrm{EC}_{50}$ values $^{1)}(\mu \mathrm{g} / \mathrm{mL})$} \\
\hline & $\begin{array}{c}\text { Leucaena leucocephala } \\
\text { leaves extracts }\end{array}$ & Vitamin C \\
\hline $\begin{array}{l}\text { DPPH free radical scavenging } \\
\text { activity }\end{array}$ & 133.51 & 39.96 \\
\hline $\begin{array}{l}\text { ABTS cation radical scavenging } \\
\text { activity }\end{array}$ & 667.22 & 51.27 \\
\hline Nitrite scavenging ability & $2,582.88$ & 344.83 \\
\hline Reducing power & 250.00 & 57.47 \\
\hline
\end{tabular}

${ }^{1)} \mathrm{C}_{50}$ values are expressed as the effective concentration at which antioxidative activities using DPPH radicals, ABTS radicals and nitrite were scavenged by $50 \%$; absorbance was 0.5 for reducing power

2006; Kim 등, 2012; Joo 2013)에서는 플라보노이드에 비해 폴 리페놀 함량이 높다고 보고되었고 백연수 잎 추출물의 결과도 이와 유사하였다. 따라서 폴리페놀과 플라보노이드 함량이 높은 백연수 잎의 $50 \%$ 에탄올 추출물을 이용하여 라디칼 소거활성, 아질산염 소거 활성, $\mathrm{Fe}^{3+}$ 이온 환원력 및 지질과산화 억제활성 을 측정함으로써 항산화 활성을 조사하였다. 동시에 천연 항산 화제인 비타민 $\mathrm{C}$ 와 비타민 $\mathrm{E}$ 를 대조 물질로 사용하여 항산화 활성을 비교하였다.

비교적 안정한 유리라디칼인 DPPH 라디칼이 항산화 물질에 의해 환원되어 탈색된 정도를 측정하여 백연수 잎 추출물의 유 리라디칼 소거활성을 확인하였다. 백연수 잎 $50 \%$ 에탄올 추출 물의 $\mathrm{DPPH}$ 유리라디칼 소거활성은 추출물의 농도에 비례하여 증가하여 $270 \mu \mathrm{g} / \mathrm{mL}$ 의 농도에서 $70.5 \%$, 비타민 $\mathrm{C}$ 는 $62.5 \mu \mathrm{g} /$ $\mathrm{mL}$ 농도에서 $78.9 \%$ 의 소거활성을 보였다(Fig. 1A). DPPH 유 리라디칼의 $50 \%$ 를 소거하는 농도인 $\mathrm{EC}_{50}$ 은 백연수 잎 추출물 이 $133.51 \mu \mathrm{g} / \mathrm{mL}$, 비타민 $\mathrm{C}$ 는 $39.96 \mu \mathrm{g} / \mathrm{mL}$ 로 계산되었다(Table 2). 백연수 종자 $80 \%$ 에탄올 추출물의 $\mathrm{DPPH}$ 유리라디칼 소거 활성의 $\mathrm{EC}_{50}$ 이 $839.56 \mathrm{mg} / \mathrm{mL}$ 라는 결과(Chowtivannakul 등, 2016)를 고려하면 백연수 잎 추출물이 종자보다 유리라디칼 소 거 활성이 매우 우수한 것으로 판단된다. 백연수 잎 추출물의 $\mathrm{DPPH}$ 유리라디칼 소거활성에 대한 $\mathrm{EC}_{50}$ 은 식용 식물 잎 중 고


Fig. 1 DPPH free radical scavenging (A) and ABTS cation radical scavenging (B) activities of 50\% ethanol extract from Leucaena leucocephala leaves. Insets were antioxidative activities of vitamin $\mathrm{C}$ as a control. Data were means and SD of triplicate measurements 

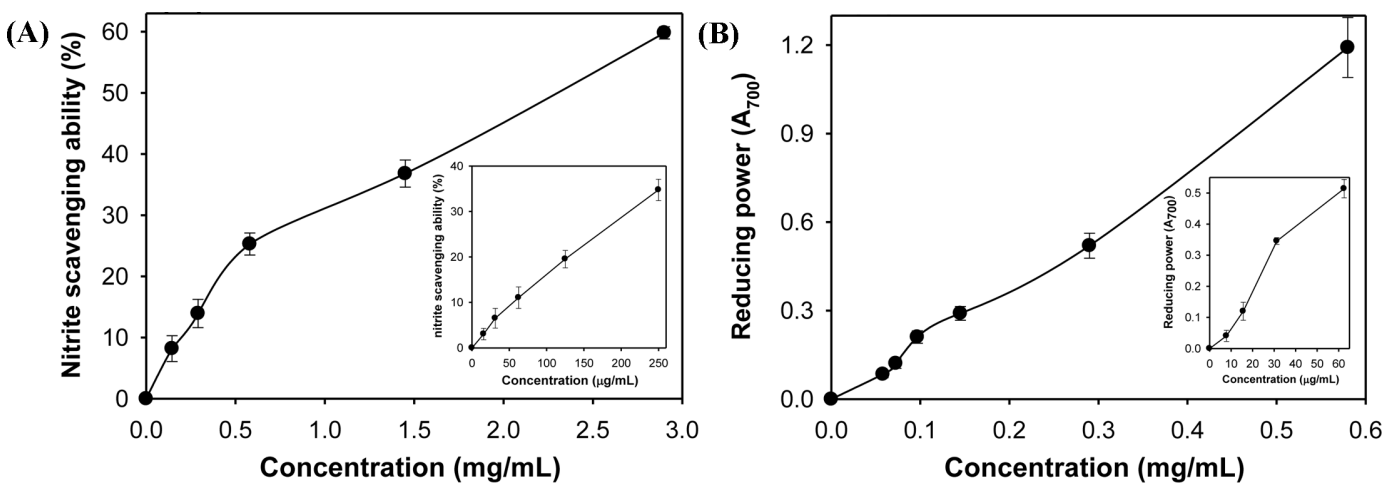

Fig. 2 Nitrite scavenging ability (A) and reducing power (B) of 50\% ethanol extract from Leucaena leucocephala leaves. Insets were antioxidative activities of vitamin $\mathrm{C}$ as a control. Data were means and SD of triplicate measurements
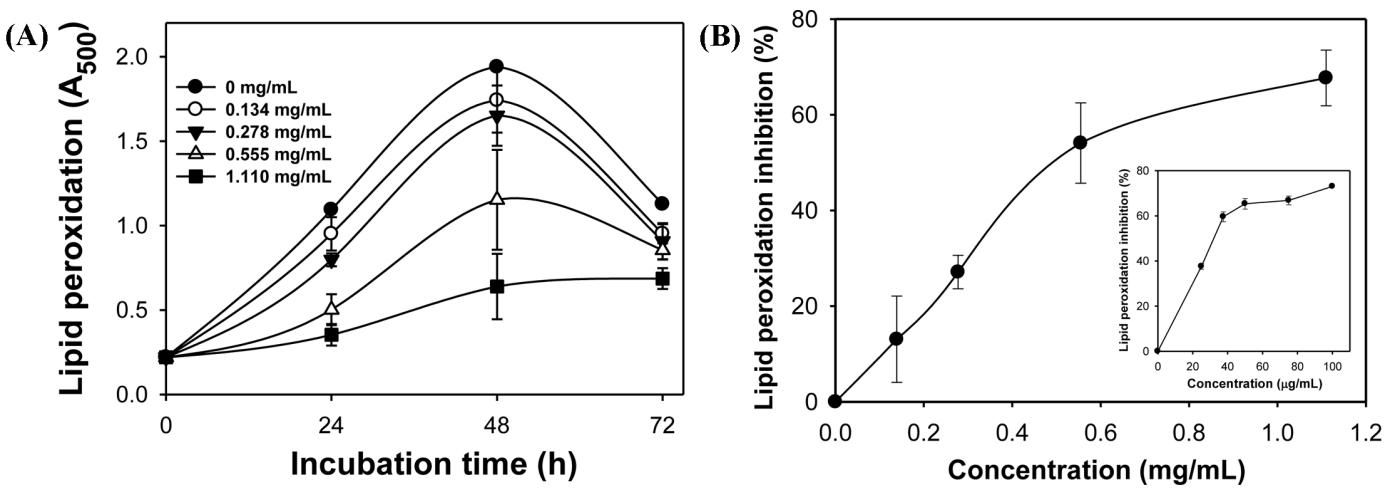

Fig. 3 Inhibition effects of 50\% ethanol extract from Leucaena leucocephala leaves on the oxidation of linoleic acid. (A) Lipid peroxidation inhibitory activity of the extract showing the peroxide formation versus the incubation time. (B) Lipid peroxidation inhibitory activity as a function of the extract concentration after $24 \mathrm{~h}$ of incubation. Insets were antioxidative activities of vitamin $\mathrm{E}$ as a control. Data were means and SD of triplicate measurements

구마 잎 $[109-168 \mu \mathrm{g} / \mathrm{mL}, 80 \%$ 에탄올 추출물 $(\mathrm{Li}$ 등, 2012)] 및 곤드레 잎 $[111.19 \mu \mathrm{g} / \mathrm{mL}$, 에탄올 추출물(Lee 등, 2006)]과 유사한 것으로 조사되었다.

$\mathrm{ABTS}$ 와 potassium persulfate를 반응시켜 생성된 $\mathrm{ABTS}^{+}$라 디칼이 항산화 물질에 의해 환원되어 탈색된 정도를 측정하여 백연수 잎 추출물의 양이온라디칼 소거활성을 확인하였다. 백연 수 잎 $50 \%$ 에탄올 추출물의 $\mathrm{ABTS}$ 양이온라디칼 소거활성 역 시 추출물의 농도에 비례하여 증가하였고, 추출물 $600 \mu \mathrm{g} / \mathrm{mL}$ 의 농도에서 $44.7 \%$ 의 소거활성을, 비타민 $\mathrm{C}$ 는 $50 \mu \mathrm{g} / \mathrm{mL}$ 농도에서 $49.8 \%$ 의 소거활성을 보였다(Fig. 1B). ABTS 양이온라디칼 소 거활성의 $\mathrm{EC}_{50}$ 은 백연수 잎 추출물이 $667.22 \mu \mathrm{g} / \mathrm{mL}$, 비타민 $\mathrm{C}$ 는 $51.27 \mu \mathrm{g} / \mathrm{mL}$ 로 계산되었다(Table 2). 물엉겅퀴, 눈개승마, 쇠 무릅과 섬고사리 잎 $70 \%$ 메탄올 추출물의 $\mathrm{ABTS}$ 양이온라디 칼 소거활성의 $\mathrm{EC}_{50}$ 이 $40.65-92.59 \mu \mathrm{g} / \mathrm{mL}$ 인 것(Lee 등, 2005 ) 과 비교하면 백연수 잎 추출물의 양이온라디칼 소거활성은 낮 은 편이었다. 백연수 잎 추출물은 양이온라디칼 보다는 유리라 디칼을 더욱 효과적으로 소거하는 것으로 나타났다.

산성조건에서 아질산염은 식품 중의 아민류와 반응하여 발암 물질인 nitrosamine이 생성될 가능성이 높다. 낮은 $\mathrm{pH} 1.2$ 의 조 건에서 백연수 잎 $50 \%$ 에탄올 추출물의 아질산염 소거활성을 측정하였다. $\mathrm{DPPH}$ 유리라디칼 소거활성과 동일하게 아질산염
소거활성도 추출물의 농도에 비례하여 증가하여 $2.9 \mathrm{mg} / \mathrm{mL}$ 의 농도에서 $59.8 \%$, 비타민 $\mathrm{C}$ 는 $0.25 \mathrm{mg} / \mathrm{mL}$ 농도에서 $34.7 \%$ 의 소거활성을 보였다(Fig. 2A). 아질산염의 $50 \%$ 를 소거하는 농도 인 $\mathrm{EC}_{50}$ 은 백연수 잎 추출물이 $2.58 \mu \mathrm{g} / \mathrm{mL}$, 비타민 $\mathrm{C}$ 는 0.34 $\mathrm{mg} / \mathrm{mL}$ 로 계산되었다(Table 2). 폴리페놀류의 화합물들은 발암 물질인 nitrosamine의 생성을 억제하는데 효과가 있으며 특히 산성조건에서 아질산염 소거효과가 우수하다는 기존 연구(Mirvish 1995)와도 잘 일치하였다. 그러므로 백연수 잎 추출물은 nitrosamine의 생성 원인 중 하나인 아질산의 분해활성을 갖는 것으로 판단되었다.

백연수 잎 $50 \%$ 에탄올 추출물이 활성 산소종 및 유리기에 전자를 공여하는 능력을 $\mathrm{Fe}^{3+}$ 를 $\mathrm{Fe}^{2+}$ 로 전환시키는 환원력으로 측정하였다. 백연수 잎 추출물의 환원력은 라디칼 소거활성 및 아질산염 소거활성과 동일하게 추출물의 농도에 비례하여 증가 하였고(Fig. $2 \mathrm{~B}$ ), 반응액의 흡광도가 0.5 가 되는데 필요한 농도 를 나타내는 $\mathrm{EC}_{50}$ 은 에탄올 추출물과 vitamin $\mathrm{C}$ 에서 각각 $250.00 \mu \mathrm{g} / \mathrm{mL}$ 과 $57.47 \mu \mathrm{g} / \mathrm{mL}$ 로 나타났다(Table 2). 백연수 잎 추출물의 환원력에 관한 연구는 대단히 미미하여 환원력이 보 고된 식용 식물과 $\mathrm{EC}_{50}$ 을 비교하면, 백연수 잎 추출물은 모시 풀잎 $[44.39 \mu \mathrm{g} / \mathrm{mL}, 70 \%$ 에탄올 추출물 $(\mathrm{Kim}$ 등, 2015)]보다 낮 고, 뽕나무 어린가지 $[500 \mu \mathrm{g} / \mathrm{mL}, 50 \%$ 에탄올 추출물(Park과 
Hong 2014)]보다 우수한 환원력을 갖는 것으로 나타났다.

지질의 산화반응 초기에 생성되는 과산화물은 $\mathrm{FeCl}_{2}$ 와 반응 하여 붉은색 색소를 형성한다(Nakatani와 Kikuzaki 1987). 본 연구에서는 linoleic acid를 기질로 하여 산화에 의해 생성되는 과산화물을 측정함으로써 백연수 잎 추출물의 지질과산화 억제 활성을 확인하였다. Linoleic acid의 산화에 의한 과산화물은 48 시간까지 증가하였고, 백연수 잎 $50 \%$ 에탄올 추출물은 시간에 따른 과산화물의 생성을 농도의존적으로 억제하였다(Fig. 3A). 과산화물은 지질 산화 초기에 발생되고 지질 산화가 진행될수 록 malonaldehyde 등의 저분자 화합물로 분해되므로 오래 산화 가 진행된 지질에서는 오히려 과산화물값이 낮게 나타난다 (Shafazila 등, 2011). 지질 산화반응 초기인 24시간에서 백연수 잎 $50 \%$ 에탄올 추출물의 linoleic acid 산화억제 활성은 추출물 의 농도에 비례하여 증가하여 $555 \mu \mathrm{g} / \mathrm{mL}$ 의 농도에서 $54.1 \%$, 비 타민 $\mathrm{E}$ 는 $50.0 \mu \mathrm{g} / \mathrm{mL}$ 농도에서 $65.4 \%$ 의 억제활성을 보였다 (Fig. 3B). 서양삼나무 잎의 ethyl acetate 추출물은 $200 \mu \mathrm{g} / \mathrm{mL}$ 의 농도에서 linoleic acid의 산화를 약 $85 \%$ 억제한다고 알려져 있고(Ismail 등, 2000), 물엉겅퀴, 눈개승마, 쇠무릅과 섬고사리 잎 $70 \%$ 메탄올 추출물은 $100 \mu \mathrm{g} / \mathrm{mL}$ 의 농도에서 linoleic acid 의 산화를 $90 \%$ 이상 억제한다는 보고(Lee 등, 2005)와 비교하 면 백연수 잎 추출물의 지질과산화 억제활성은 다소 낮은 편이 었다.

이상의 결과에서 유리/양이온라디칼 소거활성, 아질산염 소거 활성, 환원력 및 지질과산화 억제활성 측면에서 백연수 잎 $50 \%$ 에탄올 추출물의 항산화 활성이 천연 항산화제인 비타민 $\mathrm{C}$ 와 $\mathrm{E}$ 의 활성 보다 낮은 것으로 나타났으나 비타민 $\mathrm{C}$ 와 $\mathrm{E}$ 는 단일 성분이며 백연수 잎 추출물은 다양한 성분의 혼합물임을 고려 하면 백연수 잎 추출물은 우수한 항산화 활성을 갖는 것으로 사료된다. 또한 백연수 잎 유래의 천연 항산화제 성분의 규명 과 백연수 잎 추출물의 용도 확대에 대한 추가적인 연구가 필 요한 것으로 판단된다.

\section{초 록}

백연수 잎으로부터 얻어진 $50 \%$ 에탄올 추출물의 항산화능을 조 사하였다. 백연수 잎 추출물의 수율은 $18.3 \pm 0.40 \%$, 총 폴리페 놀 함량은 $121.3 \pm 11.04 \mu \mathrm{g}$ gallic acid equivalents $/ \mathrm{mg}$, 총 플라 보노이드 함량은 $105.2 \pm 2.77 \mu \mathrm{g}$ quercetin equivalents $/ \mathrm{mg}$ 으로 나타났다. 백연수 잎 추출물은 유리라디칼 소거활성, 양이온라 디칼 소거활성, 아질산염 소거활성, 환원력 및 지질과산화 억제 활성의 항산화능을 가지고 있었다. 백연수 잎 추출물의 모든 항 산화 활성은 추출물의 농도에 비례하여 증가하였으며, 유리라디 칼 소거활성, 양이온라디칼 소거활성, 아질산염 소거활성 및 환 원력의 $\mathrm{EC}_{50}$ 은 각각 $133.51,667.22,2.58$ 및 $250.00 \mu \mathrm{g} / \mathrm{mL}$ 이 었다. 백연수 잎의 우수한 항산화 활성은 높은 폴리페놀과 플 라보노이드 함량에 기인한 것으로 여겨진다.

Keywords 백연수 잎-에탄올 추출물·폴리페놀·플라보노이 드 · 항산화

\section{References}

Amin A, Yazdnparast R (2007) Antioxidant and free radical scavenging potential of Achillea santolina extracts. Food Chem 104: 21-29

Blois MS (1958) Antioxidant determination by the use of a stable free radical. Nature 181: 1199-1200

Boo HO, Lee HH, Lee JW, Hwang SJ, Park SU (2009) Different of total phenolics and flavonoids, radical scavenging activities and nitrite scavenging effects of Momordica charantia L. according to cultivars. Korean J Medicinal Crop Sci 17: 15-20

Chowtivannakul P, Srichaikul B, Talubmook C (2016) Antidiabetic and antioxidant activities of seed extract from Leucaena leucocephala (Lam.) de Wit. Agric Natural Resour 50: 357-361

Echeverría V, Belmar R, Ly J, Santos-Ricalde RH (2002) Effect of Leucaena leucocephala leaf meal treated with acetic acid or sodium hydroxide on apparent digestibility and nitrogen retention in pig diets. Animal Feed Sci Technol 101: 151-159

Folin O, Denis W (1912) On phosphotungstic-phosphomolybdic compounds as color reagents. J Biol Chem 12: 239-243

Gray JI, Dugan Jr LR (1975) Inhibition of N-nitrosamine formation in model food system. J Food Sci 40: 981-985

Ismail M, Manickam E, Danial AM, Rahmat A, Yahaya A (2000) Chemical composition and antioxidant activity of Strobilanthes crispus leaf extract. J Nutr Biochem 11: 536-542

Joo SY (2013) Antioxidant activities of medicinal plant extracts. J Korean Soc Food Sci Nutr 42: 512-519

Ju JC, Shin JH, Lee SJ, Cho HS, Sung NJ (2006) Antioxidative activity of hot water extracts from medicinal plants. J Korean Soc Food Sci Nutr 35: 714

Kim C, In MJ, Kim DC (2015) In vitro antioxidant activity of ethanol extract from Boehmeria nivea L. leaves. Food Eng Prog 19: 76-81

Kim EJ, Choi JY, Yu M, Kim MY, Lee S, Lee BH (2012) Total polyphenols, total flavonoid contents, and antioxidant activity of Korean natural and medicinal plants. Korean J Food Sci Technol 44: 337-342

Lee SH, Jin YS, Heo SI, Shim TH, Sa JH, Choi DS, Wang MH (2006) Composition analysis and antioxidative activity from different organs of Cirsium setidens Nakai. Korean J Food Sci Technol 38: 571-576

Lee SO, Lee HJ, Yu MH, Im HG, Lee IS (2005) Total polyphenol contents and antioxidant activities of methanol extracts from vegetables produced in Ullung Island. Korean J Food Sci Technol 37: 233-240

Li M, Jang GY, Lee SH, Woo KS, Sin HM, Kim HS, Lee J, Jeong HS (2012) Chemical compositions and antioxidant activities of leaves and stalks from different sweet potato cultivars. J Korean Soc Food Sci Nutr 41: $1656-1662$

López F, Garcia MM, Yanez R, Tapias R, Fernandez M, Diaz MJ (2008) Leucaena species valoration for biomass and paper production in 1 and 2 year harvest. Bioresour Technol 99: 4846-4853

Mirvish SS (1995) Role of N-nitroso compounds (NOC) and N-nitrisation in etiology of gastric, esophageal, nasopharyngeal and bladder cancer and contribution to cancer of known exposure to NOC. Cancer Lett 93: 1748

Mittal N, Mattu P, Kaur G (2016) Extraction and derivatization of Leucaena leucocephala (Lam.) galactomannan: Optimization and characterization. Int J Biol Macromol 92: 831-841

Nakatani N, Kikuzaki H (1987) A new antioxidative glucoside isolated from oregano (Origanum vulgare L.). Agric Biol Chem 51: 2727-2732

Nehdi IA, Sbihi H, Tan CP, Al-Resayes SI (2014) Leucaena leucocephala (Lam.) de Wit seed oil: Characterization and uses. Ind Crops Products 52: $582-587$

Oyaizu M (1985) Studies on products of browning reaction: Antioxidant activities of products of browning reaction prepared from glucosamine. Jap J Nutr 44: 307-315 
Pandey VC, Kumar A (2013) Leucaena leucocephala: an underutilized plant for pulp and paper production. Genet Resour Crop Evol 60: 1165-1171

Park HM, Hong JH (2014) Effect of extraction methods on antioxidant activities of Mori ramulus. J Korean Soc Food Sci Nutr 43: 1709-1715

Re R, Pellegrini N, Proteggente A, Pannala A, Yang M, Rice-Evans C (1999) Antioxidant activity applying an improved ABTS radical cation decolorization assay. Free Radical Biol Med 26: 1231-1237

Shafazila TS, Lee PM, Hung LK (2011) Inhibition of lipid peroxidation by extract and fractions of Dendrobium Sonia 'Red Bom'. $2^{\text {nd }}$ International conference on Biotechnology and Food Science 7: 19-22

Syamsudin D, Sumarny R, Simanjuntak P (2010) Antidiabetic activity of active fraction of Leucaena leucocephala (Lmk) de Wit seeds in experimental model. Eur J Sci Res 43: 384-391

Zarin MA, Wan HY, Isha A, Armania N (2016) Antioxidant, antimicrobial and cytotoxic potential of condensed tannins from Leucaena leucocephala hydrid-Rendang. Food Sci Human Well 5: 65-75 